East African Journal of Science, Technology and Innovation, Vol. 2 (1): December 2020.

This article is licensed under a Creative Commons license, Attribution 4.0 International (CC BY 4.0)

\title{
Temporal Variations in Rainfall and Temperature and their Effects on the River Discharge in the Mara River Basin
}

\author{
1, ${ }^{*}$ AYUYO O I., 1 KRHODA G O., ${ }^{1}$ MUKHOVI M S., 1 NYANDEGA A I
}

1Department of Geography \& Environmental Studies, University of Nairobi, P.O. Box 30197, Nairobi- Kenya. *Corresponding author: ongongaayuyo@gmail.com

\begin{abstract}
The Mara River basin is one of the important transboundary resources in Eastern Africa that not only serve Kenya and Tanzania where it is located as one of the waterheads but also serve the lower countries of Sudan and Egypt. Variations in weather conditions, especially rainfall and temperature in the basin have impacts beyond the basin. The environmental processes that relate to variation in weather conditions include river flow regimes, vegetation cover, agro-calendar and wildlife. This paper looked at how variations in rainfall and temperature affect the river discharge in the Mara basin in order to determine the nature of rainfall and temperature variations in relation to river discharge in the basin. Observed long-term daily rainfall, temperature and river discharge covering 1983 - 2014 period, are used in time series analyses to measure periodicity and trend in rainfall, temperature and river discharge. The relationship between river discharge and the weather elements is determined using linear correlation analysis and multiple regression procedures at $\alpha=0.05$. The results of the data analysis reveal that, the long-term variations in temperature, rainfall and river discharge are such that temperatures are tending toward increase while rainfall and river discharge are tending towards decline. Further, variations in rainfall and temperature conditions indicate un-seasonality in the timing and duration of monthly variations. The variations in rainfall, temperature and discharge series are statistically not significant (Mann Kendall trend test). The relationship between variations in rainfall and temperature with river discharge is that rainfall has stronger linear correlation with river discharge than temperature and therefore declining trends in rainfall are causing reduction in river discharge in the Mara basin. Measures should, therefore, be taken to reduce activities in the basin that are likely to impact on rainfall and temperature such as deforestation and encroachment on the water towers.
\end{abstract}

Keywords: Mara River; River discharge; Rainfall; Temperature; Trends

\section{Introduction}

The earth surface absorbs about two thirds of the sun's power with a fraction remaining reflected into the outer space as thermal energy (Le Treut et al., 2007). The absorbed power warms both the air and the ground and therefore, to establish an equilibrium on the incoming solar radiation, the earth must emit similar quantity of thermal radiation, via long wave radiation (IPCC, 2001). The energy balance initiative of the earth is however, interfered with through human induced greenhouse effect. This is because these gases allow solar energy to pass through but not the outgoing energy emitted by earth, which is instead redirected to the surface causing more

Cite as: Ayuyo et al., (2020). Temporal Variations in Rainfall and Temperature and their Effects on the River Discharge in the Mara River Basin. East African Journal of Science, Technology and Innovation 2(1).

Received:

Accepted: Published:

$02 / 09 / 20$

$23 / 11 / 20$

$11 / 12 / 20$ 
warming on the earth surface and in the atmosphere alike (IPCC, 2013; IPCC, 2007). A study by Schneider et al., (2013) that investigated the response of river flow regimes to climate change scenarios in Europe, reported that climate change would modify the flow regimes through alterations in precipitation, temperature and snow cover. The period between 1900 and 2005 showed rise in precipitation in the northern parts of Europe, eastern sections of North and South America, northern and central parts of Asia, and parts of Central and East Africa. Mediterranean and Sahel regions of Africa plus southern Asia registered a decline over the same period (IPCC, 2007). Globally, periods of rapid warming were observed between 1910 and 1930 and the period after 1970 (Herrero et al., 2010; IPCC, 2001).

Studies report that, Africa records higher temperatures than it was 100 years ago with an upward trend based on the predictions of the future greenhouse gases (GHG) triggered climate change (Christensen et al., 2017). During the $20^{\text {th }}$ Century, African region warmed up by between $0.05-0.07^{\circ} \mathrm{C}$ per decade with most warming experienced between June and November compared to the period between May and December (Hulme et al., 2007). Over the same period, the mean annual temperature in Kenya increased by $1^{\circ} \mathrm{C}$ and was expected to continue with intensified human activities, especially those that lead to deforestation and release of greenhouse gases into the atmosphere (IPCC, 2013). 1988 and 1995 recorded the warmest temperatures in Africa with 2000 recording even higher values (UNEP, 2020). Projected impacts suggest worsening situations with continued rise in temperatures and unpredictable precipitation. Predictions from existing climate contexts report that the already dry parts of the globe will intensify in dryness (Dessu et al., 2014; UNESCO, 2006) and this signals the risk of persistent drought across most African regions.

East African climate is already experiencing large variability in rain and temperature, hence occurrences of droughts together with floods (Kitheka et al., 2019; Chen et al., 2015; UNEP, 2009; Nganga, 2006). These variabilities are impacting the river flow volumes in most basins including the Mara River (Hyandye et al., 2018). According to the Government of Kenya report, (2011) Kenya is susceptible to implications of climate variability because of her reliance on agriculture as the main livelihood and high poverty level. From government sources, $80 \%$ of the farmers in Kenya depend on rain-fed agriculture and therefore, any reduction in rainfall makes most people vulnerable and food insecure (GoK, 2011). The situation is worsened by the fact that, two-thirds of Kenya is a rangeland, characterized by high temperatures and unreliable rainfall, which cannot sustain crop farming, especially during the years with extreme events like droughts (GoK, 2010). According to the reports by most studies, climate change has adversely affected the hydrological cycles and forest ecosystems in terms of species composition and communities assemblage including tree types and abundance, tree biomass, productiveness and distribution as well as hydrological regimes (Dai et al., 2016; Chen et al., 2015; Michaletz et al., 2014). This paper set out to determine the trends in observed rainfall and temperature and the resulting effects on the river discharge between 1983 and 2014 in order to understand the future climate patterns and variations in river discharge. This information was very important for a basin facing rapid increase in population and changes in land use practices that further complicate the surface water availability and river flow regimes (Mango et al., 2011; Melesse et al., 2012; Ayuyo, 2012; Ayuyo, 2020). The information in this report can offer a landing ground for evidence-based decision making in conserving the Mara River basin resources. The hypothesis of this study was 'There have been no significant temporal variations in rainfall, temperature and river discharge in the Mara river basin'.

\section{Materials and Methods}

\section{Study Area}

The Mara River basin is a trans-boundary resource shared between Kenya and Tanzania and is situated between longitudes $33^{\circ} 47^{\prime}$ and $35^{\circ} 47^{\prime} \mathrm{W}$ and latitudes $-0^{\circ} 38^{\prime}$ and $-1^{\circ} 52^{\prime} \mathrm{S}$. The river is $395 \mathrm{~km}$ long while the basin is $13750 \mathrm{~km}^{2}$ in spatial coverage. The Mara River flows 
through a sloppy gradient standing at about 3000 metres at its source in the Mau Forest in Kenya and drains into Lake Victoria at an altitude of 1134 metres at Musoma Bay in Tanzania (Mango et al., 2011; Melesse et al., 2012). Mara River is drained by a number of tributaries including the Nyangores, Amala, Talek, Sand and Engare Engito on the Kenyan side, and the rivers Mori, Kenyo, Tambora and Nyambire on the Tanzanian side (WREM International, 2008). The Nyangores and Amala sub-basins form the upstream part of the Mara River basin and are the main source of water throughout the year. Rainfall in the basin is bimodal with the main rainy season experienced from March to May while the short rains occur between September and November. The rains vary with altitude with Mau Escarpment area recording annual average rainfall ranging from $1,000-1,750 \mathrm{~mm}$, the middle rangelands from 900 to $1,000 \mathrm{~mm}$ with the lower areas around
Loita and Musoma recording between 700 and 850 mm (LVBC \& WWF-ESARPO, 2010).

The temperatures in the basin increase with decrease in altitude with mean annual maximum temperature being $25^{\circ}$ while mean minimum temperature is around $16^{\circ}$. The basin is a home to world-renowned conservancies of Maasai Mara National Reserve and Serengeti National Park, habitat for the most diverse combination of wildlife in the world, making the basin a tourism area while livestock are in the ranches. The expansive Mara has diverse land uses with crop farming as the dominant occupation followed by livestock rearing. Deforestation and cultivation in the headwaters and other fragile areas of the basin have brought about changes in rainfall-runoff characteristics and in river flow regimes (GoK, 2009). The basin is therefore, characterized by high peak stream flows and reduced base flows, enlarged river channel and siltation (Majule, 2010).

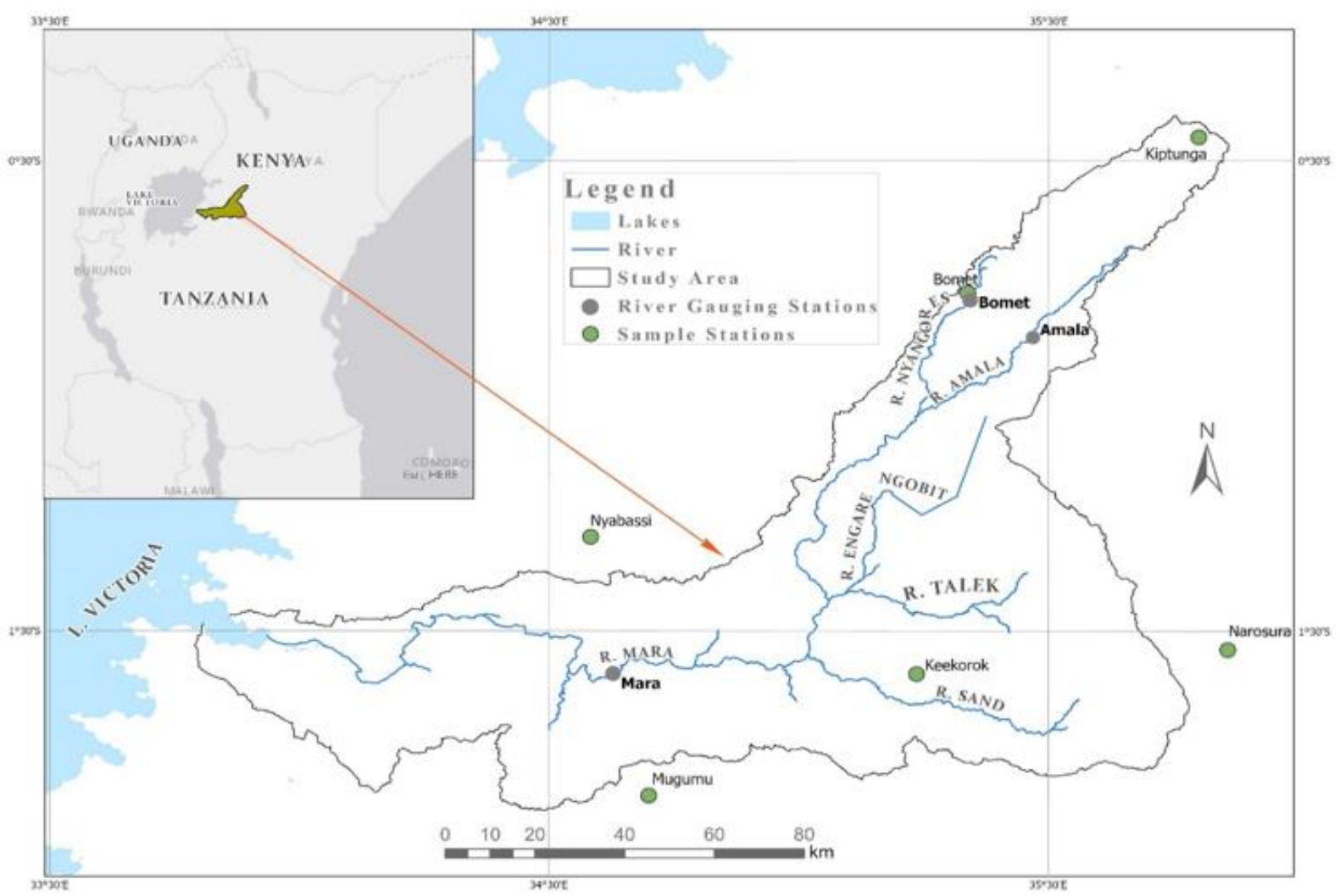

Source: Modified from WREM International, 2008

Figure 1. Location of the Mara River Basin astride Kenya and Tanzania 


\section{Data Types and Sources}

This study relied mainly on secondary data and used the observed long-term daily records of rainfall, maximum and minimum temperatures and river discharge from 1983 to 2014. The temperature and rainfall records were from the Kenya Meteorological Service (KMS) Headquarters at Dagoretti Corner in Nairobi and at the Water Resources Authority (WRA) Headquarters housed in NHIF Building at Community, Nairobi and from Tanzania Meteorological Agency, 3 ${ }^{\text {rd }}$ floor in Ubongo Plaza along Morogoro Road, Dar-es-Salaam.
The river discharge data was from the Tanzanian Water Resources Management offices in Dodoma and from the Kenya Water Resources Authority (WRA) Headquarters, NHIF Building Nairobi. The other secondary data was the Digital Elevation Model (DEM), downloaded from the United States Geological Survey Global Visualization (USGSGLOVIS) ARSTAR 30m resolution system, mainly for the delineation of the basin and mapping the topography of the basin. Other sources include books, journals and statistical abstracts from various institutions and the internet.

Table 1. Data Types and Sources

\begin{tabular}{|c|c|c|c|}
\hline Study Variable & Data Type & Data Source & Data Date \\
\hline $\begin{array}{l}\text { Long-term daily } \\
\text { records of rainfall. }\end{array}$ & Secondary & $\begin{array}{l}\text { Kenya Meteorological Service, (KMS), } \\
\text { Dagoretti, Nairobi \& Tanzania } \\
\text { Meteorological Agency, Ubongo Plaza, } \\
\text { Dar-es-Salaam. }\end{array}$ & $1983-2014$ \\
\hline $\begin{array}{l}\text { Long-term daily } \\
\text { records: Maximum } \\
\text { and minimum } \\
\text { Temperatures }\end{array}$ & Secondary & $\begin{array}{l}\text { Kenya Meteorological Service, (KMS), } \\
\text { Dagoretti, Nairobi \& Tanzania } \\
\text { Meteorological Agency. }\end{array}$ & $1983-2014$ \\
\hline $\begin{array}{l}\text { Long-term daily } \\
\text { records of river } \\
\text { discharge }\end{array}$ & Secondary & $\begin{array}{l}\text { Water Resources Authority, (WRA) at } \\
\text { Community in Nairobi, \& Water Resources } \\
\text { Management in Dodoma, Tanzania. }\end{array}$ & $1983-2014$ \\
\hline $\begin{array}{l}\text { Digital Elevation } \\
\text { Model (DEM) }\end{array}$ & $\begin{array}{l}\text { Secondary } \\
\text { (spatial) }\end{array}$ & $\begin{array}{l}\text { United States Geological Survey Global } \\
\text { Visualization (USGSGLOVIS). ARSTAR } \\
\text { 30m resolution system. Was used for basin } \\
\text { delineation and as a platform for } \\
\text { integrating the datasets, especially rainfall } \\
\text { and discharge }\end{array}$ & $16 / 01 / 15$ \\
\hline
\end{tabular}

\section{Sampling Procedure}

The selection of the weather stations of rainfall and temperature and river gauging stations for this study was guided by the location and distribution of the stations within the basin and along the river profile. Only those weather and river gauging stations that had operated for at least thirty years and had consistent records formed the target population. The sampling procedure took into account the World Meteorology Organization's requirement that a minimum network density of $600 \mathrm{~km}^{2}$ be considered when selecting rainfall and temperature gauging stations and $1875 \mathrm{~km}^{2}$ for river gauging stations (WMO, 2009). Importantly, thiessen polygons of the rainfall stations and river outlets are used together with the World Meteorological Organization's procedures to select the specific weather and river gauging stations whose records are used in the analyses. The rainfall thiessen polygons were created from the shapefiles of the rainfall stations to show the areas of the basin including the Mara River and its tributaries that are drained by water from the surrounding of each rainfall station (Figure 2). 
The network of polygons shows the proximity of each station to the river. In other words, thiessen polygons are a measure of spatial representation of the rainfall stations for purposes of inclusion in the sample. Thus, Kiptunga, Bomet, Narosura, Keekorok, Mugumu and Nyabassi were chosen based on this criteria and continuity of data. The river gauging stations of Amala and Nyangores were preferred because they are critical in their location on the two rivers, which are main tributaries of Mara River. Mara gauging station was also central in its location on the main river and data.

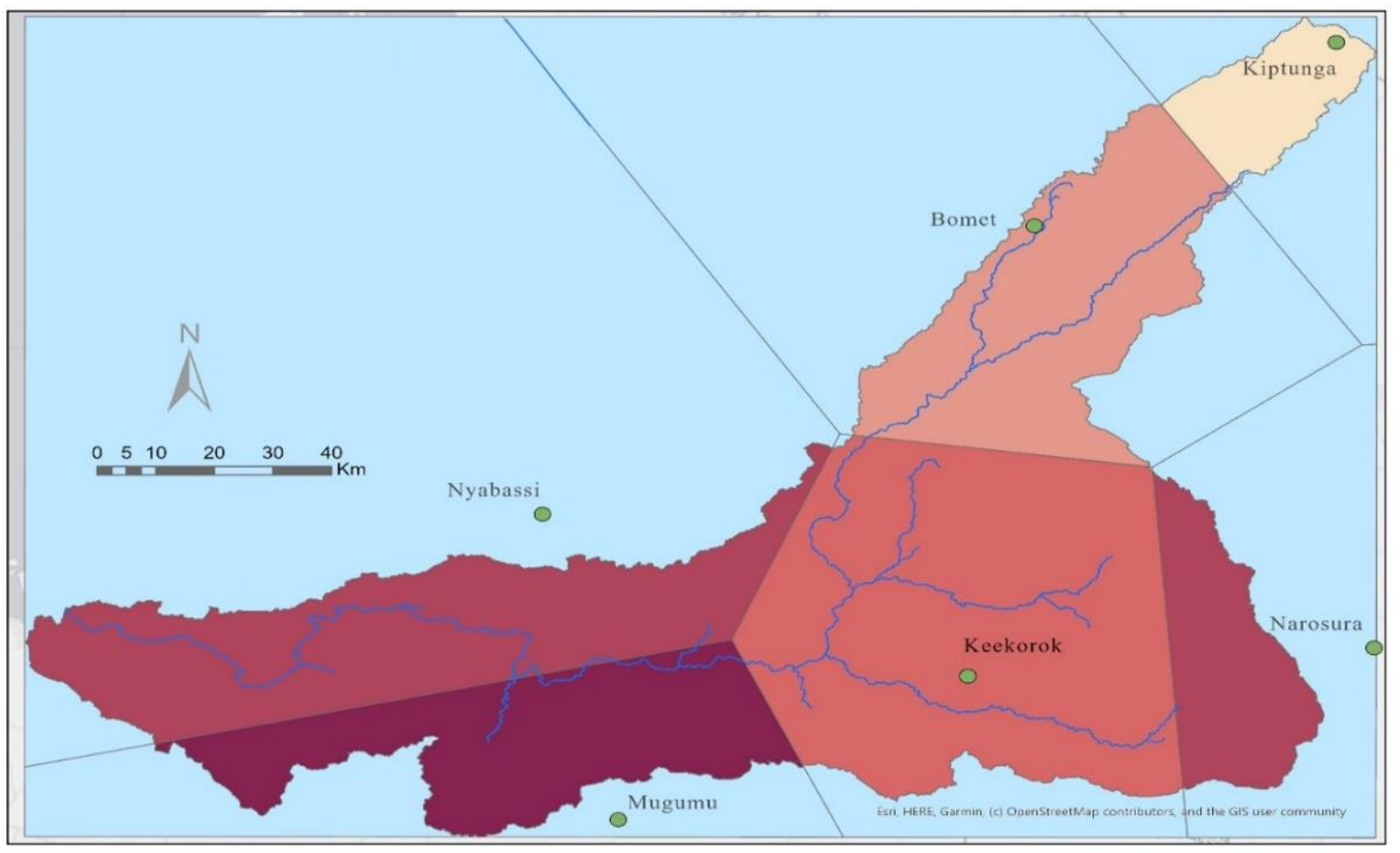

Source: Researcher, 2018

Figure 2. Thiessen Polygons as Spatial Representation Measures of Sampled Rainfall Stations

To understand the relationship between the rainfall stations and the river flow regimes in the Mara River, outlet thiessen polygons were produced using the shapefiles of all the river outlets and then matched with the rainfall thiessen polygons. This is because thiessen polygons give topographic information and distribution of the river channels that culminate in the river network and therefore the outlets. From Figure 3, an overlay of the rainfall and river outlet thiessen polygons, only three outlet points out of a total of fourteen and three out of six rainfall stations are outside the overlap area. This is an indication of a close relationship between rainfall stations and river discharge. It shows spatial contributions of the rainfall stations to river outlets and therefore the flow volumes. In other words, the rainfall within the areas served by each rainfall station flow through these outlets downstream.

The created union between the rainfall stations thiessen polygons and outlet thiessen polygons was subjected to geographically weighted regression procedure that gave standard deviations ranging between -2.5 and 2.5. This shows that each rainfall station has significant contribution of rainfall to the flow regimes in the areas indicated by the polygons (Figure 3).

\section{Data Processing and Analysis}

\section{Data Processing}

The observed hydro-meteorological data that included the long-term daily rainfall, temperature and river discharge 
measurements were in tab-delimited format and therefore, were first transferred and recorded on excel spread sheets for each month per year from 1983 to 2014 and then subjected to inconsistency checks. Importantly, continuity of data is a crucial research requirement given that, incomplete records may compromise the integrity of the results obtained from the data. Several methods are available in literature for filling in missing records of hydro-meteorological data.

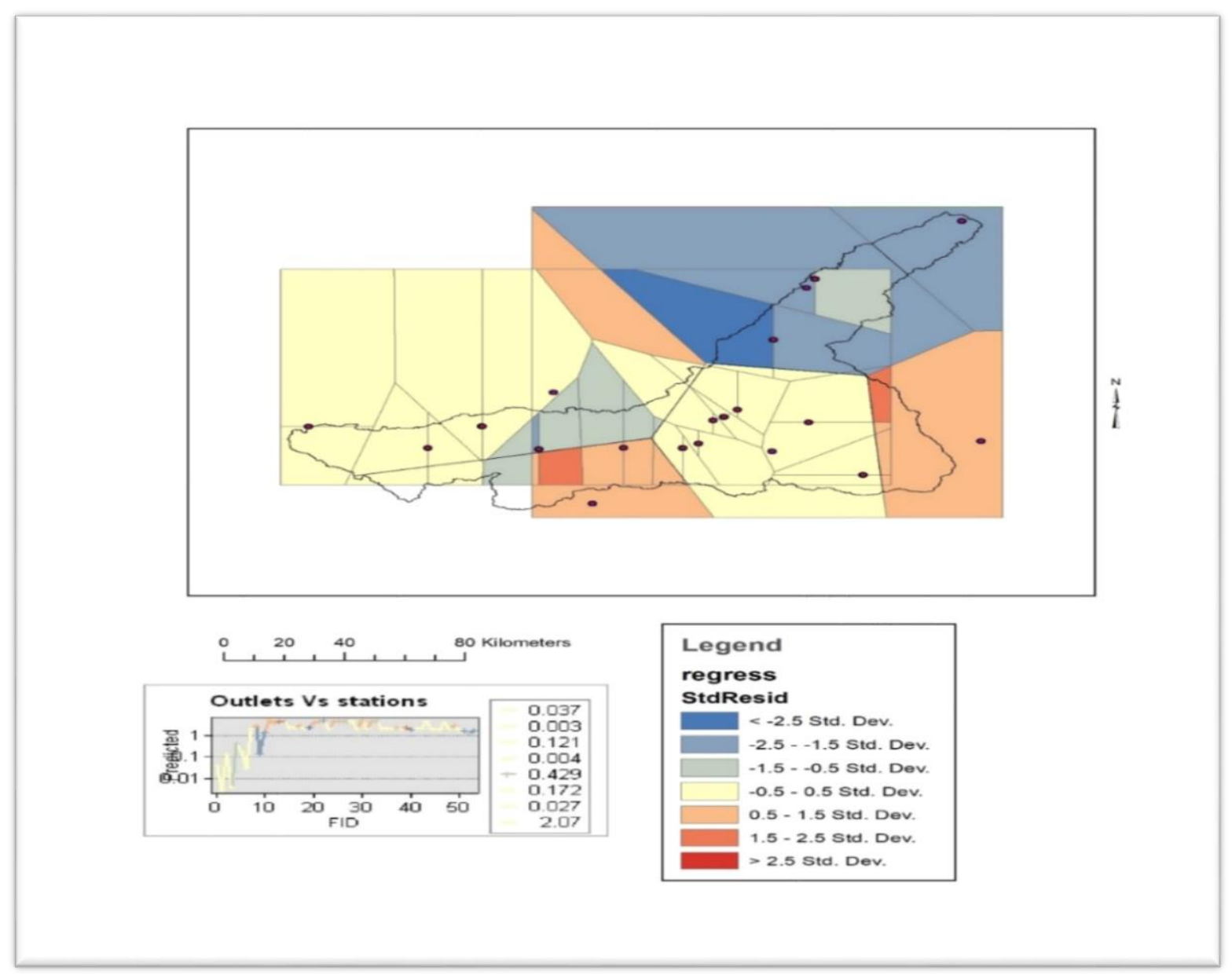

Source: Researcher, 2018

Figure 3. Spatial Relationship between Rainfall Stations and River Outlets

The methods include weighted arithmetic mean, linear regression, spatial correlation, double mass curve, inverse distance and normal ratio. The details of these methods are found in Rwigi, (2004) and Opere, (1998). This paper has used the Weighted Arithmetic Mean to estimate the missing records in rainfall, temperature and river discharge (Equation 1). The Weighted Arithmetic Mean is a popular method in filling in missing hydro-meteorological records (Opere, 1998). In this method, the missing records are estimated using corresponding records of three stations, which are close and correlated to the station with the missing records. The ratio of the normal annual rainfall of the station with missing record to that of the station with data corresponding to the missing record is used as the weighting factor.

Where:

$$
P_{x}=\frac{1}{3}\left[\frac{N_{x}}{N_{A}} P A+\frac{N_{x}}{N_{B}} P_{B}+\frac{N_{x}}{N_{C}} P_{C}\right]
$$

$P_{X}$ is the estimated missing record; $N_{X}$ is the normal annual rainfall of the station with missing records while $N_{A}$ is the normal annual rainfall of station $\mathrm{A}$. $P_{A}$ is the record in station $A$, that corresponds to the missing record in station $\mathrm{X} . N_{B}$ is the normal annual rainfall of station $B$ and $P_{B}$ is the record in station $B$ that corresponds to the missing record in station $X$; 
$N_{C}$ is the normal annual rainfall of station $C$ and $P_{C}$ is the record in station $C$ that corresponds to the missing record in station $\mathrm{X}$.

\section{Digital Elevation Model (DEM)}

In order to delineate the basin boundary for purposes of registration of the various basin parameters including the weather and river gauging stations and the topographic details, the Digital Elevation Model from the United States Geological Survey Global Visualization
(USGSGLOVIS) ASTAR 30m resolution system in raster format was first processed under Geographic Information Systems (GIS) environment. The DEM was projected and then clipped to fit the Mara River Catchment, using data transformation procedures on spheroid WGS 84 and UTM zone 36 and saved (Figure 4). Notably, DEM is widely used especially in hydrological simulation to show flow direction, calculation of flow accumulation and stream network among others.

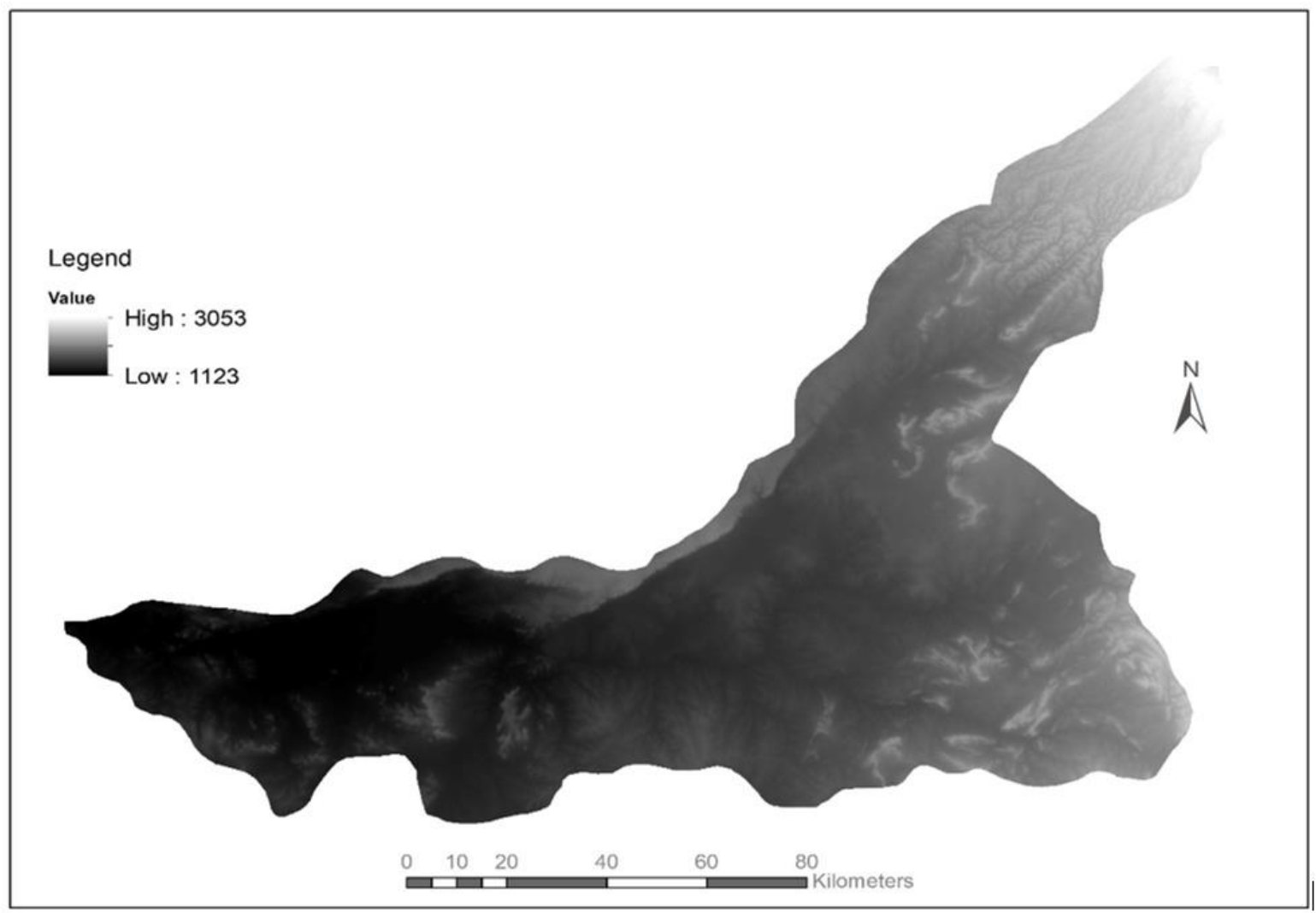

Source: U. S. Geological Survey Global Visualization System, 2015

Figure 4. Digital Elevation Model of the Study Area

\section{Time Series Analyses}

Time series analysis is a major tool in hydrological analysis with wide application areas including building mathematical models for generating synthetic hydrologic records, forecasting hydrologic events, detecting trends and shifts, cycles and seasonality in hydrologic records and filling in missing records including extension of short hydrologic records where necessary (Salas, 1993; Helsel \& Hirsch, 2002; Rwigi, 2004). There are many parametric and non-parametric methods of detecting trends. One of the most useful parametric methods of detecting trend is the simple linear regression analysis, which assumes normality of errors, constant variance and true linearity of relationships (Opere, 1998; Helsel \& Hirsch, 2002). In this paper, trends in temperature, rainfall and river discharge are determined using Mann-Kendall (MK) test, which is a nonparametric statistic. Microsoft Excel Worksheet was used for computing ten-year trends in rainfall a alongside Mann-Kendall test statistic and Multiple Linear Regression Model.

\section{Mann-Kendall test}

The (MK) test statistic has been widely used in research for detecting trends in hydro- 
meteorological time series (Opere, 1998; Douglas et al., 2000; Yue et al., 2002b; Cong et al., 2010; Burn et al., 2012; Sang et al., 2014; Chebana et al., 2017; Serinaldi et al., 2018; Wang et al., 2019). MK-test is popular because it has no requirements for homogeneity or prior assumptions on the distribution of the variables under study (Önöz \& Bayazit, 2003; Babar \& Ramesh, 2014). It is also less sensitive to abrupt breaks in data, making it suitable for analysis of variables with inconsistent or missing records like hydro-climatic data (Kendall, 1975; Hamed \& Ramachandra, 1998; Helsel \& Hirsch, 2002; Hamed, 2007; Gao et al., 2018; Dong et al., 2019; Duan et al., 2019). The limitation of this method however is that, it may not apply to too short trends since the actual scale of change variation may be inaccurate (Wasserstein et al., 2019).

\section{Sense slope estimator}

The Sen's slope estimator in MK test statistic was used to determine trends or nature of change in time series such that, a positive slope (+ value) indicate increasing trend over a specified period. Equally, a negative slope (value) reports a decreasing trend over a period. Generally, for any given time series, say $\left\{X_{i}, i=\right.$ $1,2 \ldots, n\}$, the null hypothesis $\left(\mathrm{H}_{0}\right)$ assumes independent distribution while the alternative hypothesis $\left(\mathrm{H}_{1}\right)$, existence of a monotonic trend. The strength of the trend or magnitude of change is proportionate to the test statistic $S$, which is the total Sgn of the whole time series (Equation

$$
\operatorname{Sgn}=\left(x_{j}-x_{k}\right)=\left\{\begin{array}{l}
1 \text { if } x_{j}>x_{k} \\
0 \text { if } x_{j}=x_{k} \\
-1 \text { if } x_{j}<x_{k}
\end{array}\right.
$$

Equation 2 is computed as:

$$
S=\sum_{i=1}^{n} \sum_{j=k+1}^{n} \operatorname{sign}\left(x_{j-} x_{i}\right)
$$

Where $\boldsymbol{x}_{\boldsymbol{j}}-\boldsymbol{x}_{\boldsymbol{k}}$ is the indicator function resulting in the values $-1,0,1$ according to the sign of $\boldsymbol{x}_{\boldsymbol{j}}-\boldsymbol{x}_{\boldsymbol{k}}$ where $\mathrm{j}>\mathrm{k}$. Assuming that $\boldsymbol{x}_{\boldsymbol{j}}-$ $\boldsymbol{x}_{\boldsymbol{k}}=\theta$, the value $\operatorname{sign} \theta$ is computed as

$$
\operatorname{sign} \theta=\left\{\begin{array}{l}
1 \text { if } \theta>0 \\
0 \quad \text { if } \theta=0 \\
-1 \text { if } \theta<0
\end{array}\right.
$$

This computation represents all positive differences minus all negative differences factored in the calculations.

The variance of $S$ is calculated as: var $=\frac{1}{18}\left[n(n-1)(2 n+5)-\sum_{t} f_{t}\left(f_{t}-1\right)\left(2 f_{t}+5\right)\right]$

Where: $n=$ length of data set

$t=$ number of data value in a group of determination

The standard normal deviation (z-statistic) is computed as:

$$
z=\left\{\begin{aligned}
(S-1) / s e, & S>0 \\
0, & S=0 \\
(S+1) / s e, & S<0
\end{aligned}\right.
$$

Where $s e=$ the square root of var.

During the analysis, the trend would be said to be decreasing if $Z$ is negative and the calculated probability is higher than the significance level when tested at $\alpha=0.05$. Consequently, the trend increases with positive $\mathrm{Z}$ and the computed probability is more than the significance level. When the computed probability is lower than the significance level, this indicates that there is no trend.

\section{Multiple Linear Regression Model}

Multiple linear regression model is a statistical method for studying relationship between an outcome variable (dependent variable) and several predictors (independent variables) that best represent the relationship in the model (Allison, 1999; Koklu et al. 2010; Adamu \& Ado, 2012). The model is very popular for both predictive and explanatory purposes and therefore, the most widely used statistical technique in the social, biological and physical sciences. When used for prediction like in this case, a formula is developed to help make predictions about the dependent variable based on the observed values of the independent variables (Koklu et al. 2010). Multiple linear regression model (Equation 7) is applied in this paper to establish the relationship in the rainfall, temperature and river discharge model.

$$
\begin{aligned}
Y= & \beta o+\beta 1 X 1+\beta 2 X 2+\cdots+\beta n X n+\varepsilon(7) \\
& \text { Where } \\
& Y \text { represent the dependent variable, X1 } \cdots \\
& \cdot X n \text { represent the several independent } \\
& \text { variables; } \beta o \cdot \cdot \cdot \cdot \beta n \text { represent the } \\
& \text { regression coefficient and } \varepsilon \text { represent the } \\
& \text { random error. }
\end{aligned}
$$

The strength of associations between rainfall, temperature and river discharge were measured using Pearson Coefficient of Correlation (r). The Correlation Coefficients are from -1 to +1 , where values close to zero $(0)$ mean no relation between the variables, close to -1 , strong negative correlation and close to +1 , 
strong positive correlation between the dependent and independent variable. In calculating the Correlation Coefficients, Equation 8 applied.

Where

$$
r=\frac{\sum_{i=1}^{n}(x j-\bar{x})(\boldsymbol{y} \boldsymbol{j}-\overline{\boldsymbol{y}})}{\sqrt{\sum_{i=1}^{n}(x j-\overline{\boldsymbol{x}})^{2}(y j-\overline{\boldsymbol{y}})^{2}}}
$$

$x$ represents the independent variable (in this case, rainfall and temperature);

$y$ represents the dependent variable (river discharge); $\boldsymbol{r}$ is the Correlation Coefficient,

$x j$ and $y j$ are the $j$ th observations for the two variables; $\overline{\boldsymbol{x}}$ and $\overline{\boldsymbol{y}}$ are Arithmetic Mean of the observations of the two variables while $n$ is the number of observations.

The significance of the contribution of each variable of rainfall and temperature to the river flow regimes was tested at $\alpha=0.05$, using student $\mathrm{t}$ test statistic (Equation 9).

$$
\boldsymbol{t}_{c a l}=\frac{b}{s(b)}
$$

Where: $\boldsymbol{t}_{\boldsymbol{c} \text { al }}=$ computed t-statistic; $b=$ slope of the regression line; $s(b)=$ standard deviation of the slope. The calculated t-statistic $\left(\boldsymbol{t}_{\text {cal }}\right)$ was compared with the corresponding tabulated critical value $\boldsymbol{t}_{\text {cric }}$ in which the slope was considered significant whenever the calculated $\mathrm{t}$-statistic was greater than tabulated $\mathrm{t}$ - statistic, $\boldsymbol{t}_{\text {cal }}>\boldsymbol{t}_{\text {cric }}$.

\section{Results}

\section{Temporal variations in Rainfall, Temperature} and River Flow.

The results of the analysis of the trends in observed rainfall, temperature and discharge got from Mann Kendall test statistic and Microsoft Excel Sheet are presented in this first part of the results as Trends in the Monthly and Annual Rainfall in the Mara Basin and Ten-year Trends in Mean Monthly Rainfall. Others include Ten-year Mean Monthly Rainfall Variability, Mean Annual Maximum and Minimum Temperature Variability, Trends in Monthly and Annual Maximum and Minimum
Temperatures and Mean Annual Trends in River Discharge. The last part of the results presents the results of the effect analysis from multiple regression model.

\section{Trends in the Mean Monthly and Annual Rainfall in the Mara Basin}

The results on the monthly and annual trends in rainfall reveal variability in amounts and time between 1983 and 2014, tested at 95\% confidence level. From the MK test summary (Table 2), February, March, August, September and December had positive $Z$ values, meaning an increase in rainfall in each of the months over the 1983 - 2014 period. In other words, seven out of twelve months had negative $Z$ values, and therefore reported a decrease in rainfall over the same period. Despite the monthly variations observed in rainfall between 1983 and 2014, none of the months recorded significant increase or decrease at $\alpha=0.05$. Thus, 'There have been no significant temporal variations in monthly rainfall in the Mara basin' over the study period. Such variations in monthly and annual rainfall were reported by (Muthoni et al., 2019; Wabwire et al., 2020) in their studies of spatial-temporal trends and variability in rainfall in the Lake Victoria basin, Kenya and over Eastern and Southern Africa respectively.

The annual trends results gave a negative $\mathrm{Z}$ value of -0.14 and this indicate a slight reduction in the annual rainfall values as supported by the Sen's slope (-0.017), resulting in an annual value of $-0.017 \mathrm{~mm} /$ year. Similarly, 'There have been no significant temporal variations in annual rainfall in the Mara basin over the study period. In other words, none of the monthly and or annual variations in rainfall in the Mara River indicated very different values from the previous month or year over the study period. 
Table 2. MK Test for Monthly and Annual Rainfall (1983 - 2014)

\begin{tabular}{|c|c|c|c|}
\hline Monthly/Annual & Test Z & Significance a & Sen's slope $(\mathrm{Q})$ \\
\hline January & -0.99 & Not significant & -0.765 \\
\hline February & 0.59 & $"$ & 0.396 \\
\hline March & 0.87 & “' & 0.739 \\
\hline April & -1.39 & “' & -1.745 \\
\hline May & -0.07 & $"$ & -0.098 \\
\hline June & -0.02 & $"$ & -0.028 \\
\hline July & -1.84 & “ & -0.333 \\
\hline August & 1.14 & $"$ & 0.640 \\
\hline September & 1.19 & $"$ & 0.667 \\
\hline October & -0.42 & $"$ & -0.159 \\
\hline November & -0.20 & $"$ & -0.273 \\
\hline December & 0.12 & " & 0.122 \\
\hline Annual & -0.14 & $"$ & -0.017 \\
\hline
\end{tabular}

*trend at $a=0.05$

Ten-year Mean Monthly Trends in Rainfall

The Mara basin observed rainfall data obtained from Kiptunga, Bomet, Keekorok, Narosura, Nyabasi and Mugumu rainfall stations was used to get the mean monthly average rainfall for the years 1983 - 2014 using Microsoft Excel spreadsheets. The averages were then categorized into 1980s, 1990s and 2000s data sets and graphs drawn (Figure 5) to illustrate the overall trend for each period, over the entire 30year period. The results show that the basin has bimodal rainfall pattern and this agrees with a number of reports including the work of Bartzke et al., (2018). The short rains are realized in the months of September to November (SON) while the long rains occur from March to May (MAM), with the peak in April. Comparing the three periods, 1980s, 1990s and 2000s, the 80s recorded highest peak in the long rain while 2000s registered the highest peak in the short rains. Generally, the 1990s had least rainfall than the other two periods. 


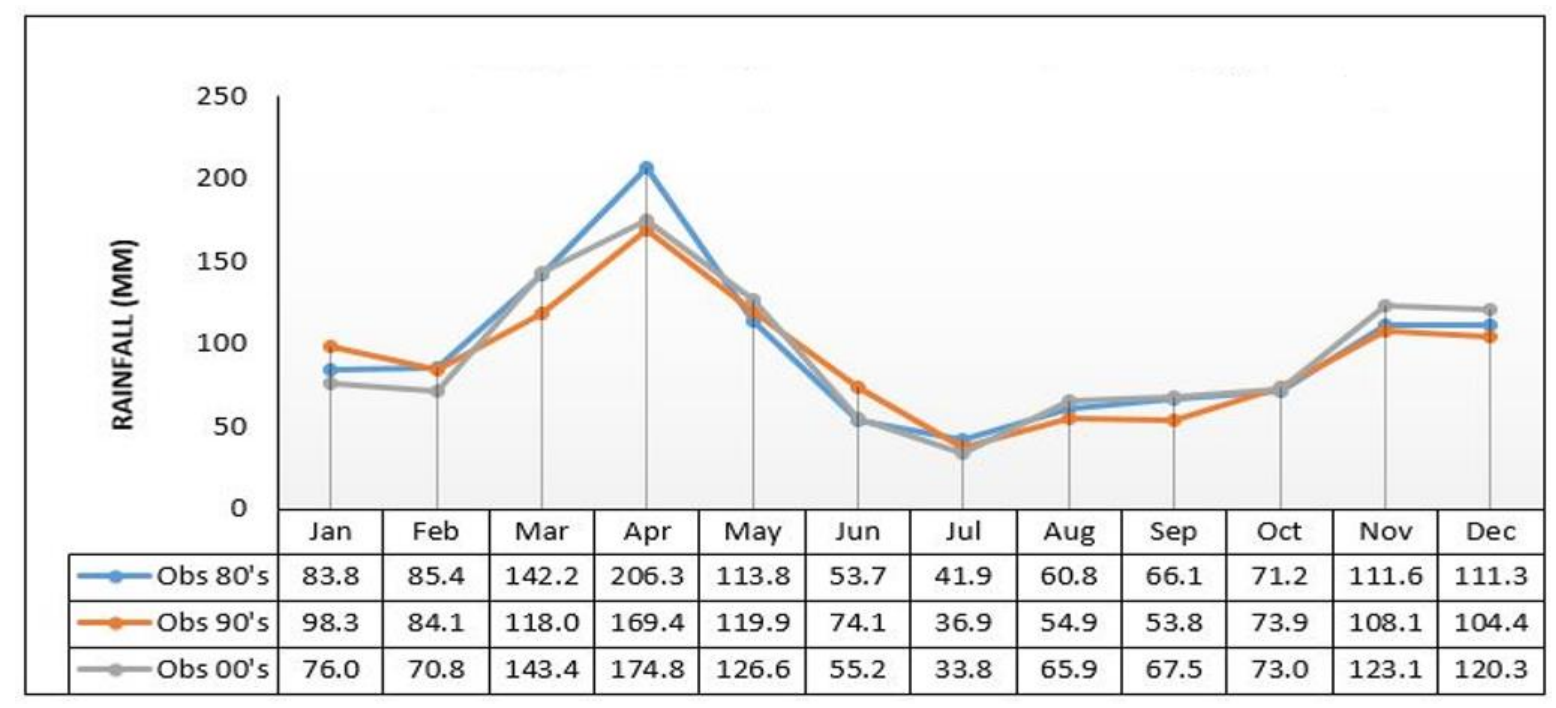

Figure 5. Trends in the Mean Monthly Rainfall for1980s, 1990s and 2000s

The period between June and August is relatively dry compared to the other months with July recording the least amount of rainfall. Observation from Figure 2 is that, the basin is experiencing reduced peak flows during the long rains and increased peak flows in the short rains. The basin is experiencing shifts in rainfall pattern with some usually dry months becoming increasingly wet and the wet months getting increasingly dry, a condition being reported by many researchers (Rwigi, 2014; Wabwire et al., 2020). In the 2000s, January and February experienced much reduction in rainfall compared to 1990s that recorded even more than the base year, with November and December recording quiet a good increase from the base year.

\section{Ten-year Mean Monthly Variability in Rainfall}

Variability of the mean monthly rainfall in this study was statistically examined using coefficient of variation (CV), which is the statistical measure of data dispersion around the mean in points in a data series. It is a percentage ratio of the standard deviation to the mean and expressed as $C_{V}=100 \cdot \frac{\sigma}{X}$

In the 90s, coefficient of variation results expressed as a percentage revealed that variability was least in the months of February,
May, October, November and December, thus signifying consistency of the rainfall patterns.

High variation on the other hand was recorded in June (38\%), September (-19\%) and April ($18 \%)$. During the 2000s period, highest variations were recorded in July (-19\%), February (-17\%) and April (-15\%) experiencing reduced rainfall. The months of March, June, September and October showed consistency below $5 \%$. Comparing the two periods, it can be noted that, whereas June had the highest variability during the 90 s, this variability was minimal in the 2000s. This period also witnessed a general increase in rainfall. According to Bartzke et al., (2018), wet season floods occurred in the Mara region between 1998 and 2012 due to increased rainfall. The witnessed decrease in rainfall in the 90s could be an attribute of increased temperatures of the northern hemisphere (Tierney et al., 2015) and perhaps the central Indian Oceans (Funk et.al, 2008; Williams \& Funk, 2011). On the contrary, in the 2000s, eight out of twelve months recorded increments while four, decreases in rainfall from the baseline. In summary, the basin recorded an insignificant increase in rainfall in the 2000s (Figure 3) compared with the 1990s 
rainfall, a period that was even drier than the 1980s.

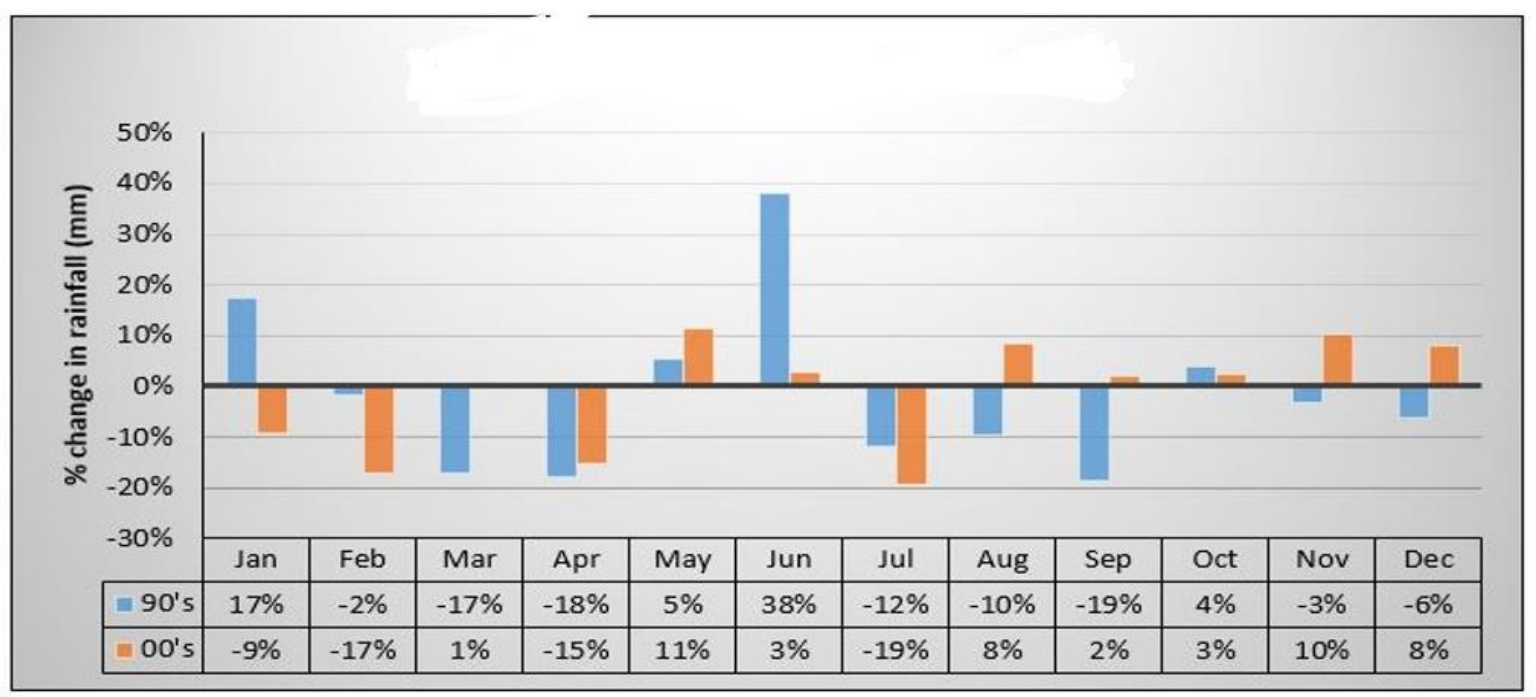

Figure 6. Variability in the Mean Monthly Rainfall -1980s, 1990s and 2000s

\section{Trends in Mean Annual Maximum and Minimum Temperatures}

The annual trends in maximum and minimum temperatures are compared through regression equations as shown in Figure 7, which also explains the variations in the two means over the study period. The two curves and trend lines indicate a gradual increase in both the mean monthly temperatures throughout the study period. Importantly, the basin formerly experienced higher mean minimum than mean maximum temperatures in the earlier years up to 2000. For the next four years (up to 2004), both the mean monthly temperatures were the same after which, the mean monthly maximum temperature became higher than the mean monthly minimum with the gap becoming wider with time, the way it was in the earlier years. The trend line equations possessing coefficients of determination, $\left(\mathrm{R}^{2}\right)$ of 0.555 for minimum and 0.652 for maximum mean monthly values indicate strong positive correlation between increase in the mean monthly values and time in years. The curves indicate clearly that, the early years of the study recorded the minimum values in the two mean monthly temperatures, with most years recording values below average between 1983 and 1994. Between 1996 and 2014, the curves shot up with the lower levels of the mean monthly minimum and maximum curves following the trend line (average value) while majority were above average with only 2008 and 2013 recording values below average in both cases. 


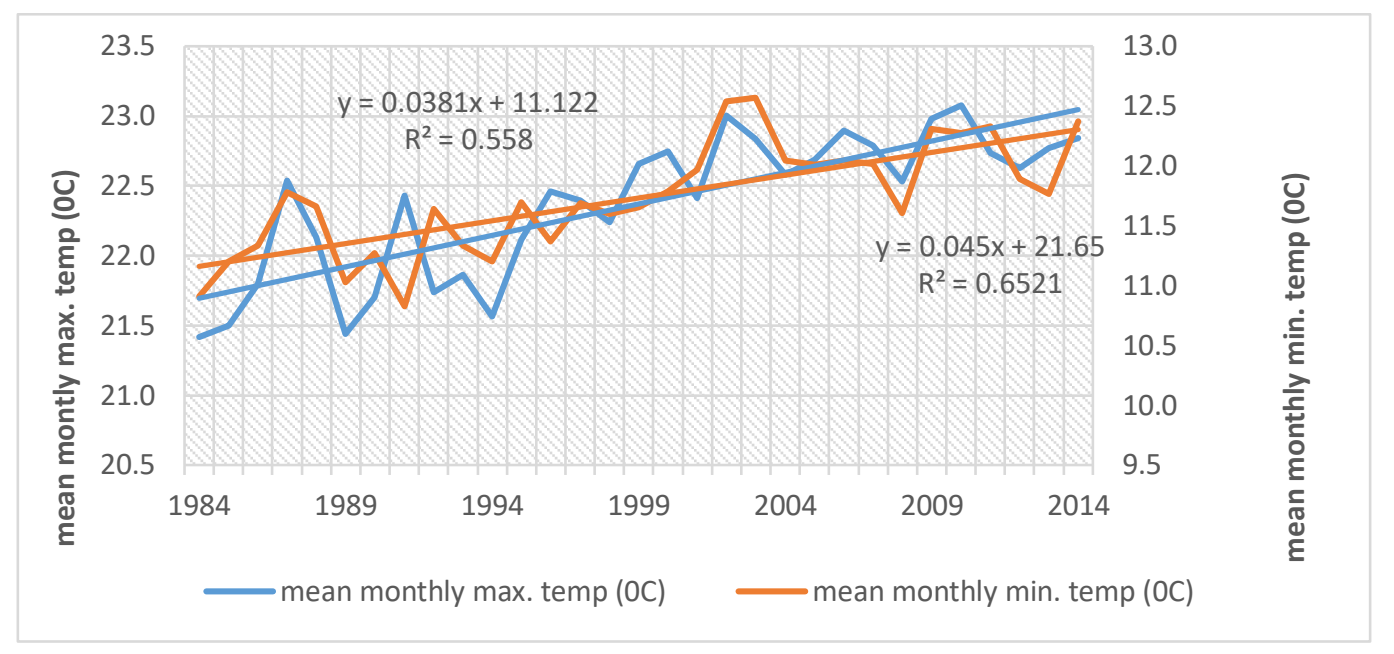

Figure 7. Mean Annual Trends in the Maximum and Minimum Temperatures

Trends in Monthly and Annual Maximum and Minimum Temperatures

Separate MK test was done for maximum and minimum temperatures and as indicated in Table 3, the $\mathrm{Z}$ values are positive for all the months for both maximum and minimum temperatures. This signifies that there has been a general increase in the maximum and minimum temperatures in the study area from 1983 to 2014. When tested at $\alpha=0.05$, changes in monthly maximum temperatures were found to be statistically significant in the months of
January, June, September, October and November. Similarly, the monthly minimum temperatures increased significantly in January, April, July and September, over the study period. Annually, the increase in both the maximum and minimum temperatures between 1983 and 2014 as indicated by the positive Z values were found not statistically significant. The Sen's slope signified that the maximum and minimum temperatures increased by 0.046 ${ }^{\circ} \mathrm{C} /$ year and $0.041^{\circ} \mathrm{C} /$ year respectively.

Table 3. MK Test for Monthly and Annual Maximum and Minimum Temperature (1983-2014)

\begin{tabular}{lrrrr}
\hline Monthly/ & \multicolumn{2}{c}{ Z test } & \multicolumn{2}{c}{ Sen's slope (Q) } \\
Annual & T. Max temp & T Min temp & Max temp & Min temp \\
\hline January & $2.36^{*}$ & $2.24^{*}$ & 0.05 & 0.051 \\
February & 4.28 & 3.31 & 0.07 & 0.061 \\
March & 3.42 & 3.26 & 0.053 & 0.058 \\
April & 2.60 & $2.26^{*}$ & 0.056 & 0.04 \\
May & 3.89 & 3.74 & 0.053 & 0.045 \\
June & $2.19^{*}$ & 1.45 & 0.033 & 0.024 \\
July & 4.18 & $2.40^{*}$ & 0.06 & 0.032 \\
August & $1.82+$ & 2.67 & 0.036 & 0.035 \\
September & $2.36^{*}$ & $2.42^{*}$ & 0.023 & 0.039 \\
October & $2.45^{*}$ & 1.53 & 0.035 & 0.026 \\
November & $1.99^{*}$ & 1.87 & 0.03 & 0.028 \\
December & 3.28 & 3.06 & 0.056 & 0.054 \\
Annual & & & & 0.046 \\
Max Temp & & & & 0.041 \\
Annual & & & & \\
Min Temp & & & &
\end{tabular}




\section{Mean Annual Trends in River Discharge}

The results of the analysis of the mean annual discharge revealed variability in discharge across the months and years. The discharge has declined over the study period, a situation expected to continue into the future as indicated by the negative slope (figure 8 ). The results agree with that of rainfall that also declined over the same period. Definitely, there is no way discharge can increase in a basin where rainfall, the main source of discharge, is decreasing. Importantly, the trends in discharge generally followed those of rainfall. An $\mathrm{R}^{2}$ of 0.0178 indicates that variations in discharge over the years are not statistically significant, whether in the dry or wet seasons. Deforestation in the headwaters is believed to be reducing base flow and therefore, low base flows during dry seasons. Conversion of forestland to cropland is also causing a decline in flow volumes because cropland allows less evapotranspiration compared with forestland, resulting in low rain formation and low discharge.

Rainfall variability affects peak flows as opposed to base flows, which are affected mainly by changes in land cover, especially deforestation. These results agree with reports by many authors including (Melesse et al., 2012). To mention a few cases, the least amount of rainfall $(600 \mathrm{~mm})$ and the least amount of discharge $\left(200 \mathrm{~m}^{3}\right)$ were recorded in 1990 (driest year) while reductions in each were recorded between 1988 and 1989 and between 2000 and
2006. The 2020 and 2023 were expected to be very dry, although 2020 may have had a difference already due to the excess rains that were observed early in the year. The highest rainfall and discharge were in 1988, 1997, 2000 and 2009. Some of these variations coincided with the El Nino phenomena in the Northern Pacific Ocean while some are linked to the variation in the Indian Ocean temperature, which influence rainfall in East Africa (Nyakwanda et al., 2009; LVBC \& WWFESARPO, 2010). The trends in rainfall and discharge indicate that dry and wet years are cyclic, appearing at least after every three years, which in most cases, coincides with the troughs and peaks of the three-year moving average line (Figure 8). In brief, the declining trends in discharge is a threat to continued supply of the very much-needed water by various users.

\section{Effects of Temperature and Rainfall on the River Discharge}

The joint effect of rainfall and temperature on discharge is shown in the model summary (Table 4), from multiple regression model. Also known as the power of the model, it gives the overall power (strength) of the regression model in predicting the dependent variable. In Table 4, the R Square is 0.633 and Adjusted R Square is 0.606 . In such a case, we use the adjusted $R$ Square to give room for the predictors not considered in the model including land cover land use, soils, slope and shape of watershed, which influence the variations in discharge.

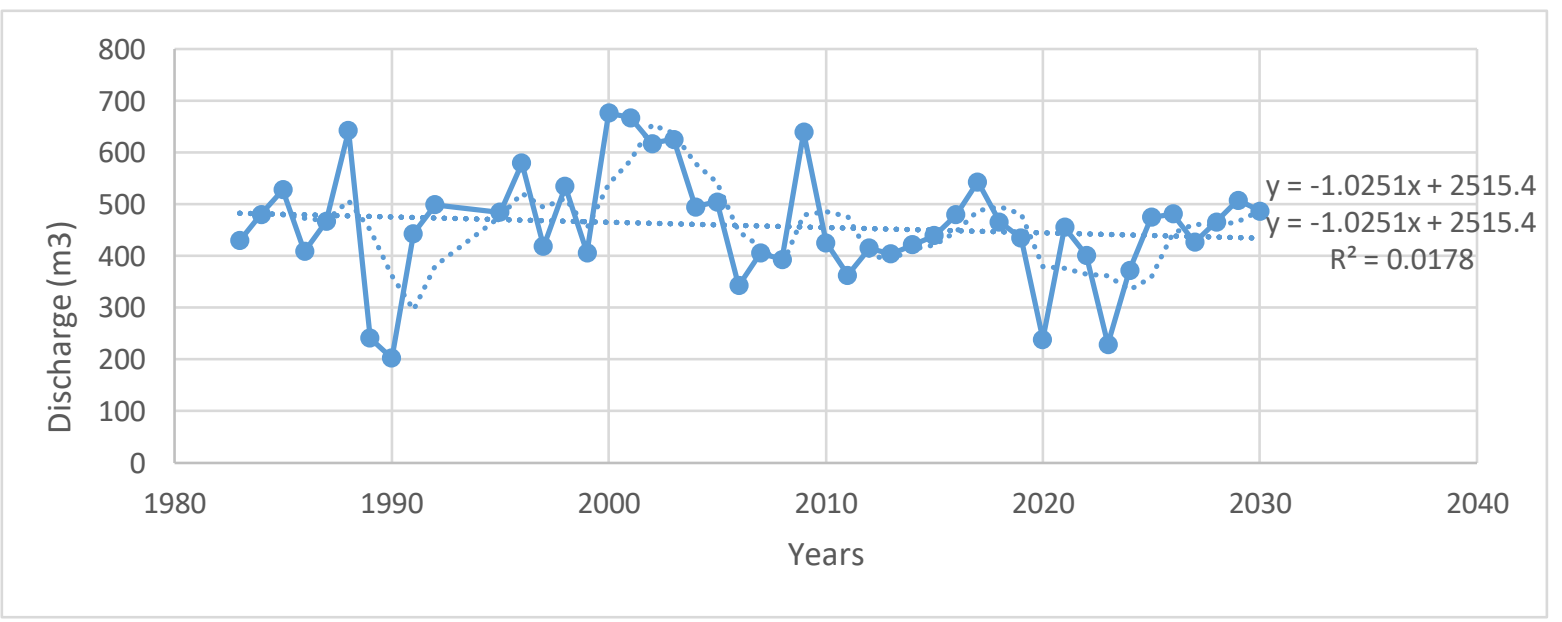

Figure 8. Mean Annual Trends in River Discharge $\left(m^{3} s^{-1}\right)$ in the Mara Basin 
Table 4. Power of the Model or Model Summary ${ }^{b}$

\begin{tabular}{|c|c|c|c|c|c|c|c|c|c|c|}
\hline \multirow[t]{3}{*}{ Model } & \multirow[t]{3}{*}{$\mathrm{R}$} & \multirow[t]{3}{*}{$\mathrm{R}^{2}$} & \multirow{3}{*}{$\begin{array}{l}\text { Adjusted } \\
\mathrm{R}^{2}\end{array}$} & Std Error & \multicolumn{5}{|c|}{ Change Statistics } & \multirow{3}{*}{$\begin{array}{l}\text { Durbin- } \\
\text { Watson }\end{array}$} \\
\hline & & & & & $\mathrm{R}^{2}$ & $\mathrm{~F}$ & df1 & df2 & Sig & \\
\hline & & & & Estimate & Change & Change & & & Change & \\
\hline 1 & $.796^{\mathrm{a}}$ & .633 & .606 & 73.13146 & .633 & 23.317 & 2 & 27 & .000 & 2.572 \\
\hline
\end{tabular}

Table 5. ANOVA Results for Predictor Variables

\begin{tabular}{|c|c|c|c|c|c|c|}
\hline \multicolumn{2}{|c|}{ Model } & \multirow{2}{*}{$\begin{array}{l}\begin{array}{l}\text { Sum of } \\
\text { Squares }\end{array} \\
249410.338\end{array}$} & \multirow{2}{*}{$\frac{\mathrm{df}}{2}$} & \multirow{2}{*}{$\begin{array}{l}\begin{array}{l}\text { Mean } \\
\text { Square }\end{array} \\
124705.169\end{array}$} & \multirow{2}{*}{$\begin{array}{l}\mathbf{F} \\
23.317\end{array}$} & \multirow{2}{*}{$\begin{array}{r}\text { Sig. } \\
.000^{\mathrm{b}}\end{array}$} \\
\hline 1 & Regression & & & & & \\
\hline & Residual & 144401.700 & 27 & 5348.211 & & \\
\hline & Total & 393812.037 & 29 & & & \\
\hline \multicolumn{7}{|c|}{ a. Dependent Variable: Discharge } \\
\hline \multicolumn{7}{|c|}{ b. Predictors: (Constant), Precipitation, Temp } \\
\hline
\end{tabular}

$\mathrm{R}^{2}$ of 0.606 means that, about $60.6 \%$ variations in discharge is explained by variations in rainfall and temperature. Coupled with an F of 23.317 and significance level of 0.000 from ANOVA (Table 5), the model is significant in predicting variations in river discharge in the Mara basin.

After establishing the suitability of this model in predicting the variations in discharge, their coefficients were used to give their individual effects or influence on discharge (Table 6). The respective ' $t$ ' values for rainfall and temperature are 6.371 and 0.539 while their $P$ values are 0.000 and 0.594. This implies that the coefficient corresponding to rainfall, 6.371 with a P of 0.000 is statistically significant in predicting variations in discharge as opposed to temperature with a coefficient of 0.539 and a $P$ of 0.594. Logically, $a^{\prime} t^{\prime}$ of 0.539 indicates a weak correlation between temperature and discharge and, coupled with a $P$ that is greater than $a=$ 0.05 , temperature is definitely not a good predictor of variations in discharge in the Mara basin.

\section{Discussions}

In spite the results from the data analysis revealing that, the long-term variations in temperature are tending towards increase while rainfall and river discharge are tending towards decline, none of them reported significant change at $\alpha=0.05$ in the Mara river basin, based on data for the period between the year 1983 and 2014 (Table 2). The annual trend of a negative $Z$ value of -0.14 supported by the Sen's slope (-0.017), and resulting in an annual rate of $-0.017 \mathrm{~mm} /$ year, are an indication that, none of the monthly and or annual variations in rainfall in the Mara River indicated very different values from the previous month or year over the study period. However, it is worth noting that, if such changes continue over the years as in the case at hand, then the implications on the Mara flow regimes for different sectors of the economy would be devastating. This is because of the fact that, Mara is a rainfall deficient basin with many livelihoods and ecological functions to support (Mango, et al., 2010). With more months indicating reduction than increase in rainfall, the basin is likely to face arid-like conditions faster than would be the case. Proactive procedures should therefore be instituted to reverse the situation for a sustainable Mara. 
Table 6. The Coefficients of the Predictors in the Model

\begin{tabular}{|c|c|c|c|c|c|c|c|c|c|c|c|c|}
\hline \multirow{2}{*}{$\begin{array}{l}\text { Model } \\
\end{array}$} & \multicolumn{2}{|c|}{$\begin{array}{l}\text { Unstandard } \\
\text { ized } \\
\text { Coefficients }\end{array}$} & \multicolumn{3}{|l|}{$\begin{array}{l}\text { Standard } \\
\text { ized } \\
\text { Coefficie } \\
\text { nts }\end{array}$} & \multicolumn{2}{|c|}{$\begin{array}{l}95 \% \\
\text { Confidence } \\
\text { Interval for } \\
\text { B }\end{array}$} & \multicolumn{3}{|c|}{ Correlations } & \multicolumn{2}{|c|}{$\begin{array}{l}\text { Collinearity } \\
\text { Statistics }\end{array}$} \\
\hline & B & $\begin{array}{l}\text { Std } \\
\text { Erro } \\
\mathrm{r}\end{array}$ & Beta & $t$ & Sig & $\begin{array}{l}\text { Low } \\
\text { er } \\
\text { Bou } \\
\text { nd }\end{array}$ & $\begin{array}{l}\text { Upp } \\
\text { er } \\
\text { Bou } \\
\text { nd }\end{array}$ & $\begin{array}{l}\text { Zer } \\
\text { o } \\
\text { ord } \\
\text { er }\end{array}$ & $\begin{array}{l}\text { Part } \\
\text { ial }\end{array}$ & $\begin{array}{l}\mathrm{Pa} \\
\mathrm{rt}\end{array}$ & $\begin{array}{l}\text { Tolera } \\
\text { nces }\end{array}$ & VIF \\
\hline $\begin{array}{ll}1 & \text { (Const } \\
\text { ant) }\end{array}$ & $\begin{array}{l}- \\
442 . \\
233\end{array}$ & $\begin{array}{l}497 . \\
887\end{array}$ & & $\begin{array}{l}.88 \\
8\end{array}$ & $\begin{array}{l}.3 \\
82\end{array}$ & $\begin{array}{l}- \\
1463 \\
.88\end{array}$ & $\begin{array}{l}579 . \\
351\end{array}$ & & & & & \\
\hline Temp & $\begin{array}{l}16.9 \\
93\end{array}$ & $\begin{array}{l}31.5 \\
32\end{array}$ & .066 & $\begin{array}{l}.53 \\
9\end{array}$ & $\begin{array}{l}.5 \\
94\end{array}$ & $\begin{array}{l}- \\
47.7 \\
05\end{array}$ & $\begin{array}{l}81.6 \\
90\end{array}$ & $\begin{array}{l}.28 \\
7\end{array}$ & .103 & $\begin{array}{l}.06 \\
3\end{array}$ & .919 & $\begin{array}{l}1.0 \\
89\end{array}$ \\
\hline Precip & .678 & .106 & .775 & $\begin{array}{l}6.3 \\
71 \\
\end{array}$ & $\begin{array}{l}.0 \\
00 \\
\end{array}$ & .459 & .896 & $\begin{array}{l}.79 \\
3\end{array}$ & .775 & $\begin{array}{l}.74 \\
2 \\
\end{array}$ & .919 & $\begin{array}{l}1.0 \\
89\end{array}$ \\
\hline
\end{tabular}

a. Dependent Variable: Discharge

Although the basin has bimodal rainfall as reported from the results, the declining trends and shifts in the rainfall patterns in the basin is a source of worry to water resources stakeholders. The long rains had highest peak of more than $220 \mathrm{~mm}$ in the $80 \mathrm{~s}$, about $170 \mathrm{~mm}$ in the $90 \mathrm{~s}$ and $180 \mathrm{~mm}$ in 2000s. This is on the contrary to the short rainfall peaks that gave 2000s to have had the highest peak, about $130 \mathrm{~mm}$ with $90 \mathrm{~s}$ recording the least (Figure 5). Notably, months like December, July and a few others tended to witness increments in rainfall than the usual trend. The opposite is the case with the months of March, April and September, which reported declining trends in the three periods. Such outcomes are reported in previous studies (Rwigi, 2014; Wabwire, et al., 2020). The mean monthly rainfall variations are widening with time, reflecting in reduced mean annual amounts over the study period. Changes in climatic conditions and human activities, especially deforestation and water abstraction are the reasons behind these variations in rainfall (Mango et al., 2011). Encroachment on the water tower and increase in water abstraction due to population increase (Mango et al., 2010) is threatening the sustainability of the Mara resources since it will result in low or no rainfall with time. The variability in rainfall (especially the abnormally high rainfall) in the basin is attributed to the influence of the easterly air stream of the Indian Ocean monsoons and the large-scale thermal winds of Lake Victoria. These two wind systems are said to work together with the low-level westerly winds from the Atlantic Ocean to bring in the Congo air mass which tends to enhance the rainfall in the area including the months that would otherwise be dry (Nyakwanda et al., 2009).

Rainfall variability in the 1990s and 2000s from the base period, 1980s had revealed some months to have consistent rainfall patterns while some had high variability across the periods. For example, the 90s has revealed least variability in the months of February, May, October, November and December, thus signifying consistency of the rainfall patterns. High variation on the other hand was recorded in June $(38 \%)$, an increase with reductions in September (-19\%) and April (-18\%). The 2000s period recorded high variations in July $(-19 \%)$ February (-17\%) and April (-15\%), all reductions in rainfall while the months of March, June, September and October showed consistency below 5\% (Figure 6). Importantly, majority of the months in the two periods had rainfall of less than $2 \%$, an indication of declining trends in rainfall.

The declining trends in the long-rains in the months of March, April and May (Figure 6) could be of great concern to the management of the water resources, given that, this is the main rainy season (Tierney et al., 2015). The unseasonality variations in rainfall that has no 
timing and duration of monthly and the general decrease in rainfall have direct effects on the Mara river discharge and general water supply in the catchment area (Mango et al., 2011; Bartzke, et al., 2018). The witnessed decrease in rainfall in the $90 \mathrm{~s}$ could be attributed to increased temperatures of the northern hemisphere (Tierney et al., 2015) and perhaps the central Indian Oceans (Funk et.al, 2008; Williams \& Funk, 2011). Reduction in rainfall in the Mara basin, especially in the 90's could have resulted in negative long-term effects particularly on both the domestic and wild herbivores due to lack of water, pasture, and serious reduction in Mara flow regimes with implications on livelihoods (Bartzke, et al., 2018). The significance of the increased rains on the other hand in the 2000s is that, wildlife gets displaced by floods (Ogutu, et.al, 2013) and increase in animal diseases like anthrax and Rift Valley Fever (Bartzke, et al., 2018).

The Sen's slope signified that the maximum and minimum temperatures increased by 0.046 ${ }^{\circ} \mathrm{C} /$ year and $0.041{ }^{\circ} \mathrm{C} /$ year respectively over the study period. The coefficients of determination of 0.555 for minimum and 0.652 for maximum mean monthly values indicate strong positive correlation between increase in the mean monthly values and time in years. This increase in mean monthly and annual values in the Mara is of great significance to the Mara river basin resources because Mara is largely marginal ecosystem. Increase in temperature encourages evapotranspiration in vegetation cover and evaporation from open water bodies. Continued rise in air temperature is a challenge to the Mara river flow volumes because so much evaporates without replacement as seen from decrease in rainfall, especially during dry periods (Figure 7).

The observed river discharge data from Bomet, Amala and Mara gauging stations was used to compute variations in the mean annual river discharge for the years 1983-2014 using Microsoft Excel spreadsheets (Figure 8). The results of the analysis revealed variability in discharge over years with 1990 recording the least value of $200 \mathrm{~mm}$ followed by 1988 , about $240 \mathrm{~mm}$. The year 2000 reported the highest discharge of about $680 \mathrm{~mm}^{3}$ with 2001, 2002, 2003, 2009 and 1987 recording equally high flows. Reportedly, these years coincided with years with high amounts of rainfall including El Nino (Mango et al., 2011). The years with sharp drops included 1998, 2004, 2006 and 2011 with the trend line equation $y=-1.0251+2515.4$ indicate declining trend in discharge and this agrees with the declining trend in rainfall, which is the main source of the discharge in the Mara. R Square of 0.0178 show an insignificant trend of change in discharge. Variations in climatic conditions are believed to be resulting in increased erratic or abnormally high rains in the basin, which are normally unexpected (Mango et al., 2011; Bartzke, et al., 2018). Importantly, the declining rainfall in the basin will worsen the river flow regimes with implications on various economic systems and biodiversity.

From the model summary (Table 4), the R Square is 0.633 while Adjusted R Square is 0.606, and express joint effect of rainfall and temperature on discharge. Importantly, the Adjusted R Square of 0.606 and used to assess the model $(60.6 \%)$, and allowed for the effects of the predictors not in the model. Analysis of variance gave $\mathrm{a}^{\prime} \mathrm{t}^{\prime}$ of 23.317 and a $\mathrm{P}$ of 0.000 , meaning that, the model of made of rainfall, temperature and discharge is statistically significant in predicting discharge in the Mara (Table 5 ). We look at the Coefficients of the Predictor in the Model to get the effect of each predictor on discharge (Table 6) Regression Coefficients corresponding to the predictor variables of rainfall and temperature are $t=6371$ and $\mathrm{P}=0.000$ while for temperature, $\mathrm{t}=-0.539$ and $\mathrm{P}=0.594$. Thus, precipitation (rainfall) is statistically significant in predicting the river discharge since it has a positive' $\mathrm{t}$ ' and a ' $\mathrm{P}$ ' which is less than 0.05 , level of significant. From the emanating situation, temperature is not a good predictor of discharge, if left on its own. This is because much of the contribution from temperature is indirect, passing through evapotranspiration. Evapotranspiration is the means through which variations in land cover/land use affect variations in river discharge (Homdee et al., 2011). 


\section{Conclusions}

Results show that both maximum and minimum temperatures have gradually increased while rainfall and discharge on the other hand, have gradually decreased in amounts and spatial extent over the study period. The trends are likely to continue should the prevailing conditions remain unchanged. All the variables indicated increases and decreases in their monthly and yearly values based on the year in question and time of the year. There is a shift in rainfall patterns such that the expectedly wet months of March, April and May have become relatively dry while dry months of September, December; among others have become abnormally wet. The trends in rainfall and discharge indicate that dry and wet years come in clusters of at least three years, usually coinciding with the troughs and peaks of the three-year moving average line shown in Figures 5 and 8 .

The increasing trends in temperature, reduction in rainfall together with anthropogenic factors like abstraction and deforestation as reported by (Ayuyo et al., 2020, Melesse et al., 2012; Mango et al., 2011), among others, are affecting the Mara River flows that are experienced in low base flows and high peak flows especially during

\section{References}

Adamu Mustapha and Ado Abdu (2012). Application of Principal Component Analysis and Multiple Regression Models in Surface Water Quality Assessment. Journal of Environment and Earth Science www.iiste.org ISSN 2224-3216 (Paper) ISSN 2225-0948 (Online) Vol 2, No.2, 2012.

Allison, P.D., (1999). Multiple Regression: A Primer. A Sage Publications Company 2455 - Teller Road Thousand Oaks, California 91320 (850) 499 - 4224.

Ayuyo, (2012). Geospatial Analysis of Land Cover and Land Use Change in the Mau forest complex of Kenya. MA Thesis, University of Nairobi Kenya.

Ayuyo, I.O., Krhoda, G. O. and Mukhovi, S. M., (2020). Land Cover and Land Use years of low and excessive rains respectively. Although the rainfall, temperature and discharge nexus are good, enough model for predicting variations in the river discharge in the Mara, variations in rainfall has a stronger correlation with variations in discharge and therefore is a better predictor in the variations in discharge than variations in temperature. Therefore, the decreasing trends in rainfall in the Mara Basin have negative effects on the Mara discharge. Moreover, since the basin is already vulnerable to the effects of droughts and floods alike, there is need for infrastructural development to mitigate their adverse effects, especially on the river flow volumes and water availability for the various water users in the basin.

\section{Author Contributions}

AIO conceptualized the research topic and methodology and wrote the draft manuscript; GO and SM reviewed the manuscript and helped in forming the paper while IAN assisted in methodological issues of the paper.

Change in the Mara River Basin: Geospatial Approach. International Journal of Agriculture, Environment and Bioresearch Vol. 5, No. 05; 2020. ISSN: 2456-8643. https://doi.org/10.35410/IJAEB.2020. 5554.

Babar, S. and Ramesh, H. Analysis of extreme rainfall events over Nethravathi basin.

ISH J. Hydraul. Eng. 2014, 20, 212-221, doi:10.1080/09715010.2013.872353.

Bartzke, G. S., Ogutu, J. O., Mukhopadhyay, S., Mtui, D., Dublin, H. T., and Piepho, H. P. (2018). Rainfall trends and variation in the Maasai Mara ecosystem and their implications for animal population and biodiversity dynamics. PloS one, 13(9), e0202814. 
Burn, D. H., Hannaford, J., Hodgkins, G. A., Whitfield, P. H., Thorne, R., and Marsh, T. (2012). Reference hydrologic networks II. using reference hydrologic networks to assess climate-driven changes in streamflow. Hydrol. Sci. J. 57, 1580-1593.

doi:

10.1080/02626667.2012.728705

Chebana, F., Aissia, M. A. B., and Ouarda, T. B.

M. J. (2017). Multivariate shift testing for hydrological variables, review, comparison and application. J. Hydrol. 548, 88-103. doi: 10.1016/j.jhydrol.2017.02.033

Chen, X., Kumar, M. and Mcglynn, B.L., (2014). Variations in streamflow response to large hurricane-season storms in a Southeastern US watershed. J. Hydrometeorol.

http://dx.doi.org/10.1175/JHM-D-14-0044.

Christensen, J.H., Hewitson, B., Busuioc, A., Chen, A., Gao, X., Held, I., Jones, R., Kolli, R.K., Kwon, W.T., Laprise, R., Magaña Rueda, V.L., Mearns, Menéndez, C.G., Räisänen, J., Rinke, A., Sarr, A. and Whetton, P. (2007): Regional Climate Projections. In: Climate Change 2007: The Physical Science Basis. Contribution of Working Group I to the Fourth Assessment Report of the Intergovernmental Panel on Climate Change [Solomon, S., D. Qin, M. Manning, Z. Chen, M. Marquis, K.B. Averyt, M. Tignor and H.L. Miller (eds.)]. Cambridge University Press, Cambridge, United Kingdom and New York, NY, USA, 847-871.

Cong, Z., Zhao, J., Yang, D., and Ni, G. (2010). Understanding the hydrological trends of river basins in China. J. Hydrol. 388, 350-356. doi:
Dai, Erfu, Zhuo Wu, and Quansheng Ge (2016). "Predicting the responses of forest distribution and aboveground biomass to climate change under RCPs scenarios in southern China." Global Change Biology, 2016: 3642-3661.

Dessu, S.B., Melesse, A.M., Bhat, M.G. and McClain M.E. (2014). Assessment of water resources availability in the Mara River Basin. CATENA 115(O) 104-114 doi:

http://dx.doi.org/10.1016/j.catena. 2013.11.017.

Dong, J., Crow, W. T., Duan, Z., Wei, L., and Lu, Y. (2019). A double instrumental variable method for geophysical product error estimation. Remote Sens. Environ. 225, 217-228. doi: 10.1016/j.rse.2019.03.003

Douglas, E. M., Vogel, R. M., and Kroll, C. N. (2000). Trends in floods and low flows in the United States: impact of spatial correlation. J. Hydrol. 240, 90-105. doi: 10.1016/S0022-1694(00)00336-X

Duan, Z., Tuo, Y., Liu, J., Gao, H., Song, X., and Zhang, Z., (2019). Hydrological evaluation of open-access precipitation and air temperature datasets using SWAT in a poorly gauged basin in Ethiopia. J. Hydrol.569, 612-626. doi: 10.1016/j.jhydrol.2018.12.026

Funk, C., Dettinger, M. D., Michaelsen, J. C., Verdin, J. P., Brown, M. E., Barlow, M., and Hoell, A. (2008). Warming of the Indian Ocean threatens eastern and southern African food security but could be mitigated by agricultural development. Proceedings of the national academy of sciences, 105(32), 11081-11086. 
Gao, H., Li, H., Duan, Z., Ren, Z., Meng, X., and Pan, X. (2018). Modelling glacier variation and its impact on water resource in the Urumqi Glacier no. 1 in Central Asia. Sci. Tot. Environ. 644, 11601170. doi: 10.1016/j.scitotenv.2018.07.004

GoK (2009). Report of the Prime Minister's Task Force on the Conservation of the Mau Forests Complex, available online: http://www.kws.go.ke/export/sites/k ws/info/ maurestoration/maupublications/Mau Forest Complex Report. Pdf, last access: 15 June 2009.

GoK (2010). Rehabilitation of the Mau Forest Ecosystem. A Project Concept Prepared by the Interim Coordinating Secretariat, Office of the Prime Minister, on Behalf of the Government of Kenya.; Kenya Forest Service: Nairobi, Kenya, 2010; p. 19;.

GoK, (2011). Agricultural Sector Development Support Programme. Ministry of Agriculture, September Sci Clim Change 6: 249. doi:10.4172/2157-7617.1000249, 2011.

Hamed, K. H. (2007). Improved finite-sample Hurst exponent estimates using rescaled range analysis. Water Resour. Res. 43, 797-809. doi: 10.1029/2006WR005111

Hamed, K. H., and Ramachandra Rao, A. (1998). A modified Mann-Kendall trend test for auto-correlated data. J. Hydrol. 204, 182196. doi: 10.1016/S0022-1694(97)00125-X

Helsel D.R. and Hirsch R.M., (2002) Hydrological analysis and interpretation: statistical methods in water resources. US Geological Survey, Reston, VA.
Herrero, M., Thornton P.K., Notenbaert A.M., Wood S., Msangi S., Freeman H.A., Bossio D., Dixon J., van de Steeg J., Lynam J., Parthasarathy Rao P., Macmillan S., Gerard B., McDermott J., Seré C., and Rosegrant M.W. (2010). Smart investments in sustainable food production: revisiting mixed crop livestock systems. Science 327:822-825.

Homdee, T. Pongput, K. and Kanae, S. (2011). "Impacts of Land Cover Changes on Hydrologic Responses: A Case Study of Chi River Basin, Thailand Annual Journal of Hydraulic Engineering, JSCE, Vol.55, 2011, February

Hulme, M, Doherty, R. M., Ngara, T. New M. G. and Lister D., (2001). "African Climate change: 1990 - 2100." Climate Research, 2001: 145-168.

Hyandye, C.B., Worqul, A., Martz, L.W. and Muzuka, A.N.N., (2018). The impact of future climate and land use/cover change on water resources in the Ndembera watershed and their mitigation and adaptation strategies. Environ Syst Res (2018) 7:7 https://doi.org/10.1186/s40068-0180110-4

IPCC, (2001). Climate Change 2001. Impacts, Adaptations and Vulnerability. Contribution of Working Group II to the Third Assessment Report of the Intergovernmental Panel on Climate Change. Cambridge, UK: Cambridge University Press, 2001.

IPCC, (2007). Climate Change, 2007: Synthesis Report. Contribution of Working Groups I, II and III to the Fourth Assessment Report of the Intergovernmental Panel on Climate Change [Core Writing Team, 
Pachauri, R.K and Reisinger, A. (Eds.). IPCC, Geneva, Switzerland.

IPCC, (2013). Climate change 2013: the physical science basis: Working Group I contribution to the Fifth assessment report of the Intergovernmental Panel on Climate Change. Cambridge University Press.

Kendall, M. G., (1975). Rank Correlation Methods. London: Charles Griffin and Company Limited.

Kitheka, J.U., Mwangi, S. and Mwendwa, P.K., (2019). The effect of rainfall variability and landuse/land cover change in a small tropical river basin in Kenya. Int J Hydro. $\quad$ 2019;3(1):58-64. DOI: 10.15406/ijh. 2019.03.00163

Koklu, R., Sengorur, B. and Topal, B. (2010) "Water quality assessment using multivariate statistical methods, a case study: Melen River system," Water Resource management, (24)5: 959-978.

Le Treut, H., Somerville, R., Cubasch, U., Ding, Y., Mauritzen, C., Mokssit, A., Peterson T. and Prather, M. (2007): Historical Overview of Climate Change. In: Climate Change 2007: The Physical Science Basis. Contribution of Working Group I to the Fourth Assessment Report of the Intergovernmental Panel on Climate Change [Solomon, S., D. Qin, M. Manning, Z. Chen, M. Marquis, K.B. Averyt, M. Tignor and H.L. Miller (eds.)]. Cambridge University Press, Cambridge, United Kingdom and New York, NY, USA, 93-127.

LVBC and WWF-ESARPO, (2010). Assessing Reserve Flows for the Mara River. Nairobi and Kisumu, Kenya.
Majule, A. E., (2010). “Towards sustainable management of natural resources in the Mara river basin in Northeast Tanzania". Institute of Resource Assessment, University of Dar es Salaam, Tanzania.

Mango, L.M., Melesse, A.M., McClain, M.E., Gann, D. and Setegn, S.G. (2010). "Land use and climate change Impacts on the hydrology of the Upper Mara River Basin, Kenya: Results of a modeling study to support better resource management." Hydrol Earth Syst Sci, 2010: 2245-2258.

Mango, L.M., Melesse, A.M., McGann, D. and Setegn, S.G., (2011). Land use and climate change impacts on the hydrology of the upper Mara River Basin, Kenya: results of a modeling study to support better resource management. Hydrology and Earth System Sciences 15, 2245-2258. European Geosciences Union.

Melesse, A.M., McClain, M., Wang, X., Abira, M., and Mutayoba, W., (2012). Modeling the Impact of Land-Cover and Rainfall Regime Change Scenarios on the Flow of Mara River, Kenya. 2012, 1-10, doi: 10.1061/40976(316)558.

Michaletz, S. T., Cheng, D. and Kerkhoff, A. J., (2014). "Convergence of terrestrial plant production across global climate gradients." Nature, 2014: 39-43.

Muthoni, F.K., Odongo, V.O., Ochieng, J., Mugalavai, E.M., Mourice, S.K., Hoesche-Zeledon, I., Mwali, M. and Bekunda, M., (2019). Long-termspatialtemporaltrendsandvariabilityofrainfallo verEastern and Southern Africa. Theoretical and Applied Climatology 
(2019)

137:1869-1882

https://doi.org/10.1007/s00704-018-

2712-1.

Nganga, J. K., (2006). Climate change impacts, vulnerability and adaptation assessment in East Africa, paper presented at the United Nations Framework Convention on Climate Change (UNFCCC) African Regional Workshop on adaptation, Accra, Ghana, 21-23 September 2006.

Nyakwanda W., Ogallo, L. A., and Okoola R. E., (2009). The Atlantic-Indian Ocean Dipole and its influence on East African seasonal rainfall, Journal of Meteorology and Related Sciences, Kenya Meteorological Society, J. Meteorol. Rel., 3 3-12.

Ogutu, J., Owen-Smith, N., Piepho, H. P., Said, M. Y., Kifugo, S. C., Reid, R. S. and Andanje, S. (2013). Changing wildlife populations in Nairobi National Park and adjoining Athi-Kaputiei Plains: collapse of the migratory wildebeest. The Open Conservation Biology Journal, 7(1).

Önöz, B., and Bayazit, M. (2003). The power of statistical tests for trend detection. Turkish J. Eng. Environ. Sci. 27, 247-251. doi: 10.3906/sag-1205-120

Opere, A.O, (1998). Space-Time characteristics of stream flow in Kenya. PhD Thesis, University of Nairobi Kenya: 1-23.

Owen-smith, N. (1990). Demography of a large herbivore, the greater kudu Tragelaphus strepsiceros, in relation to rainfall. The Journal of Animal Ecology, 893-913.

Prins, H. H. T., and Weyserhaeuser, F. J. (1987). Epidemics in populations of wild ruminants: Anthrax and impala, rinderpest and buffalo in Lake Manyara
National Park, Tanzania [Natural selection]. Oikos (Denmark).

Rwigi, S.K, (2004): Comparative Case Study of Rainfall - Runoff Models over the Nyando River Basin. MSc Thesis, University of Nairobi, Kenya: 18 - 22.

Rwigi, S. K., (2014). Analysis of Potential Impacts of Climate Change and Deforestation on Surface Water Yields from the Mau Forest Complex Catchments in Kenya. PhD Thesis, University of Nairobi.

Sang, Y.-F., Wang, Z., and Liu, C. (2014). Comparison of the MK test and EMD method for trend identification in hydrological time series. J. Hydrol. 510, 293-298. doi: 10.1016/j.jhydrol.2013.12.039

Schneider, C., Laize, C.L.R., Acreman, M.C. and Flörke, M., (2013). Hydrol. Earth Syst. Sci., 17, 325-339, 2013 www.hydrolearth-syst-sci.net/17/325/2013/ doi: 10.5194/hess-17-325-2013.

Serinaldi, F., Kilsby, C. G., and Lombardo, F. (2018). Untenable nonstationarity: an assessment of the fitness for purpose of trend tests in hydrology. Adv. Water Resour. 111， 132-155. doi: 10.1016/j.advwatres.2017.10.015

Tierney, Ummenhofer, and deMenocal, (2015). Past and future rainfall in the Horn of Africa. Science advances, 1(9), e1500682.

UNEP, (2009). Treaties and Ratification, UNEP Ozone Secretariat, 2009, http://ozone.unep.org (accessed 2 September 2012).

UNEP Treaties and Ratification Available online: 
https://ozone.unep.org/treaties/viennaconvention (accessed on Jul 29, 2020).

UNESCO, (2006). Water: a shared responsibility. The UN World Water Development Rept 2. UNESCO, Paris.

Wabwire E.O., Mukhovi, S.N. and Nyandega, I.A., (2020). The Spatial and Temporal Characteristics of Rainfall over the Lake Victoria Basin of Kenya between 1987 and 2016. Atmospheric and Climate Sciences, $\quad 10, \quad 240-257$. https://doi.org/10.4236/acs.2020.10201 3.

Wang, S., Zuo, H., Yin, Y., Hu, C., Yin, J., and Ma, X., (2019). Interpreting rainfall anomalies using rainfall's nonnegative nature. Geophys. Res. Lett. 46, 426-434. doi: 10.1029/2018GL081190

Wasserstein, R. L., Schirm, A. L., and Lazar, N. A. (2019). Moving to a world beyond " $p$ $<0.05$ ". Am. Statist. 73, 1-19. doi: 10.1080/00031305.2019.1583913

Water Resource Management Authority (WRA), Kenya (2008). Catchment Management Strategy Lake Victoria South Catchment Area, Water Resource Management Authority, Nairobi, Kenya, 2008.
Williams, A. P., and Funk, C. (2011). A westward extension of the warm pool leads to a westward extension of the Walker circulation, drying eastern Africa. Climate Dynamics, 37(11-12), 2417-2435.

Wilson, S., Hassel, D., Hein, D., Jones R. and Taylor, R., (2009). Installing and using the Hadley Centre regional climate modelling system, PRECIS; version 1.8.2, precis.metoffice.com, September 11, 2009, 167.

WMO, (2009). Guide to Hydrological Practices, Volume II Management of Water Resources and Application of Hydrological Practices. WMO - No. 168 Sixth Edition 2009.

WREM International Inc., (2008). Mara River Basin Monograph, Mara River Basin Trans-Boundary Integrated Water Resources Management and Development Project, Final Technical Report, Atlanta, December 2008, 446p.

Yue, S., Pilon, P., Phinney, B., and Cavadias, G. (2002b). The influence of autocorrelation on the ability to detect trend in hydrological series. Hydrol; Process. 16, 1807-1829. doi: 10.1002/hyp.1095 